\title{
Pitch Movement in Javanese Language Use: \\ Lesson Learned from People accross-Generations in Yogyakarta Municipality
}

\author{
Henry Yustanto \\ Faculty of Cultural Sciences, \\ Universitas Sebelas Maret \\ Surakarta, Indonesia \\ henryyustanto@staff.uns.ac.id
}

\author{
Chattri Sigit Widyastuti \\ Faculty of Cultural Sciences \\ Universitas Sebelas Maret \\ Surakarta, Indonesia \\ chattri_sw@staff.uns.ac.id
}

\begin{abstract}
Intonation, the accurate high-low tonal speech of presentation, serves a very fundamental role in a language speech community. This intonation shows pitch movement as well as intonation contour of a speech. Speech intonation within a language society is varied from one generation to the next. Such differences possibly intervened by a number of affecting factors including age, the influence of foreign languages, in addition to the environmental influence. For that reason, personal intonation may change. The changes and differences on intonation is also seen in the language expression by Javanese language community in Yogyakarta. The speeches intonations expressed by the first, second, and third groups of generation reflect different use of pitch movement. This article aims to determine whether speech intonations distinguish pitch movement in the Javanese speaking groups accross generations in Yogyakarta. To provide sufficient explanation and answers regarding the purposed problems, several steps or approach are applied. The instrumental phonetic approach, a way of examining speech (especially in declarative, interrogative, and imperative type of sentences) is used in this study. Furthermore, to calculate and realize the analysis, the accurate measuring instrument of computer and Praat's software assistants were used. The measurement and descriptions of pitch movement were conducted by adopting the IPO strategic phases (Instituut voor Perceptie Onderzoek). The main activities undertaken in acoustic research using this approach include: 1) speech production experiments, 2) speech acoustic analysis, and 3) speech perception experiments.
\end{abstract}

Keywords-intonation; pitch movement; generation; Javanese language of Yogyakarta

\section{INTRODUCTION}

Prosodics or particular use of suprasegmental elements reflect certain perceptions in the minds of speaking partners. A speech accompanied by a well-organized suprasegmental elements relatively produced a well-perceived information. On the contrary, if an utterance produced by disorganized suprasegmental elements may lead to be wrong perceived. At the semantic level, prosodics provide information on which parts refer either to new or old information (Ball and Muller, 2005, p. 108) or which part indicates the core of information and which parts are not. At the pragmatic level, listeners often pay particular attention to the speaker's prosodic tones.

The prosody or acoustic character within a languagespeaking community is varied from one age of group to another, or even from one generation to the succeedings. It means that there is a change of acoustic characters from one generation to the next. In Yogyakarta Municipality society, one age group with the other share different typical prosody use. The present Javanese prosodi may be found vary from among the Javanese speakers' prosodics of long generations ago.

Prosodic studies in several regional languages in the Indonesian archipelago conducted by several researchers, Sugiyono (2003) examined the linguistic aspects of using computer programs. This study is entitled Pemarkah Prosodi Kontras Deklaratif nan Interogatif Pada Bahasa Melayu Kutai seeks to find the prosodic parameters indicating the linguistic aspects of declarative and interrogative types of Kutai Malay language use. Roosman (2003) in his research entitled Fonetik Eksperimental pada Prosodi Kata dan Kalimat bahasa Betawi Melayu dan Batak Toba, described the prominent and marking effects of temporal and melodic structures from two different regional languages in Indonesia, namely Batak Toba, which is identical to the typical language of stress, and the Malay language of Betawi Malay, a non-stress language. Syarfina (2008) in her study entitled Ciri Akustik sebagai Pemarkah Sosial Penutur Bahasa Melayu Deli discussed the acoustic features characterizing Melayu Deli community social groups, in the sense that the acoustical features present in Malay Deli identifiable as the speakers' social markers. Syarfina's study aims to define acoustic features which characterize social groups.

Furthermore, Ningsih (2017) in her academic disertation Karakteristik Prosodi Pada Penutur Autism Spectrum Disorder Tipe Verbal: Sebuah Pendekatan Fonetik Eksperimental, aims at 1) contrasting characteristics of the prosodic elements in children with autism spectrum disorder (ASD) verbal type, 2) describing speech intonation in children with ASD verbal type, and 3) formulating markers of prosody abnormalities in children with ASD verbal type. This paper aims to reveal the pitch movement of Javanese sentences produced by people of Yogyakarta Municipality across generations. Through this study, it is expected to produce specific guideline of the Javanese pitch movement patterns, and further contribute to the development of Javanese lessons both in high schools level and university in particular. 


\section{MethodS}

\section{A. Research Setting}

This study took a research location at the Kodya (Municipality) of Yogyakarta. This regional area was chosen for a number of consideration. First, Yogyakarta Municipality is the center of Javanese culture besides Surakarta. Second, in this regional area, both Javanese customs and norms are highly integrated and thus upheld by the community. Third, it is a city of trade, students, and tourism centers, Yogyakarta Municipality can be the main attraction for in it there is a strong undergoing cultural preservation.

\section{B. Research Data}

The data analysis segments in this study applied an experimental method. This method is used to carefully scrutinizing and measuring the acoustic speech features, in addition to calculating the respondents' assessments on the data being tested. This research data is in Javanese speech ngoko which reflect typical prosodic characteristics. The data were obtained from an experiment of declarative mode speech production of Javanese language practiced by people of Yogyakarta Municipality. To obtain the data, this study applied purposive sampling. The informants involved in this study are those who were divided into several variables and classified according to the social level of generation or age $(\geq$ 50 years old, 25-49 years old and 17-24 years old) in addition to the classification based on gender types (male and female).

\section{Technique of Analyzing Data}

The data used in this study are the prosodic characteristics in declarative. imperative, and interrogative modes of Javanese speech of language spoken by the community living in Yogyakarta Municipality. The data was technically collected through recording the sentences used by Javanese speaking target of respondents. Having collected the data, furthermore, data segmentation was undertaken by sorting the selected data into a single segment, in this case the segmentation was accomplished by displaying the classified segments in per-sentence, per-single segment, up to sounds per-sound. Having accomplished segmetation on the data, the stage of stylization or simplification of the intonation contour was done to obtain the fundamental frequency curve (F0). This stylization was a basic frequency simplification steps by way of eliminating the considered irrelevant of F0 detail,. The obtained results are the close copy stylization which contains only all relevant pitch movement. The prosodic feature of speech measurement and description was undertaken by observing the IPO (Instituut voor Perceptie Onderzoek), an approach developed by Hart, et al (2006, pp. 66).

Statistical numbers obtained from the results of stylization were further analyzed through statistical analysis. To know the significance of statistical test, it is used signification number. The result of statistical test was significant if only the significance number is smaller or equal to 0.05 . This number showed that out of a hundred data analyzed; only $5 \%$ are not supportive. In contrast to $95 \%$ of the amount of supporting data. The 0.05 number of significance indicates a significant difference, whereas the significance number of 0.01 commonly called highly significant, quite real, or quite meaningful (Sudjana, 1989, p.230).

\section{FINDINGS AND DISCUSSION}

To obtain pitch movement description that occured in each language users' generation, stylization was meant to obtain its 'close copy'. On stitilization of sentence data with subjectpredicate (SP) speech pattern; basic tone (BT) is a tone that initiates a speech, final tone (FT) a tone that ends a speech, tone range (TR) is the tone range in a speech, and the final tone excursion (FTE) is a drifting tone of the basic tone, this is illustrated in below description, table 1 .

TABLE I. The Significances Of Basic Tone (BT), Final Tone (FT), TONE RANGE (TR) AND FINAL TONE EXCURSION (FTE) DeClarative SENTENCES OF SubJeCt-Verb (S-V) PATtern DHEWEKE NGOMBE 'He DRINKS'

\begin{tabular}{|c|c|c|c|c|}
\hline & BT $(\mathrm{Hz})$ & FT $(\mathrm{Hz})$ & TR $(\mathrm{Hz})$ & FTE $(\mathrm{Hz})$ \\
\hline $\begin{array}{c}17-24 \text { years } \\
\text { old }\end{array}$ & 196,8835 & 141,2274 & 107,7198 & $-55,6561$ \\
\hline $\begin{array}{c}25-49 \text { years } \\
\text { old }\end{array}$ & 181,0329 & 108,3074 & 99,0521 & $-72,7255$ \\
\hline $\begin{array}{c}50 \text { years old } \\
\text { and over }\end{array}$ & 173,1211 & 125,1731 & 107,7564 & $-47,9480$ \\
\hline Significance & 0,590 & 0,077 & 0,891 & 0,410 \\
\hline
\end{tabular}

The above table shows the difference in the significance calculation of BT, FT, TR, and FTE with numbers of significance were above 0.05 . Thus, in such a case, there were no differences in between BT, FT, TR, and FTE significances associated with the age group between 17-24 years old (hereinafter referred to as group 1), the age group of 25-49 years (hereinafter referred to as group 2), and age group 50 years old and over (hereinafter referred to as group 3 ). The similarities in BT, FT, TR, and FTE were on the basis of behavioral, customs, cultural similarities which have long been internalized in the subjects,and then those automatically applied upon producing sentences, there occur similar melodious patterns. A comprehensive comparison between BT, FT, TR, and FTE identifiable from the following graph:

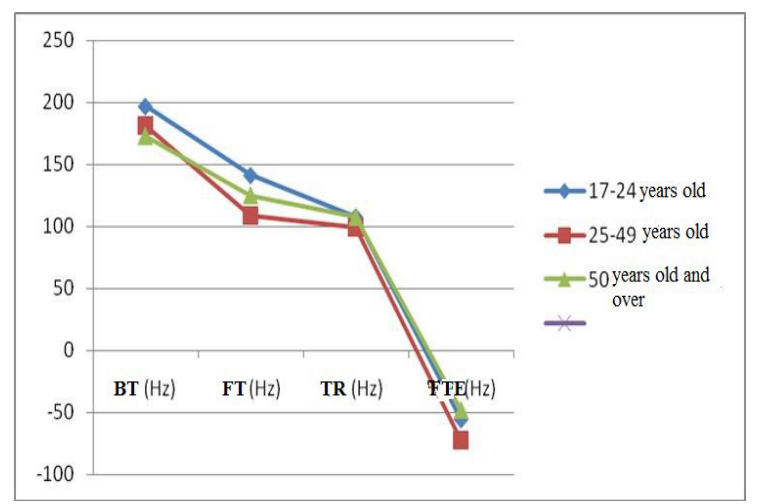

Fig 1. The comparison between basic tone (BT), final tone (FT), tone range (TR), and final tone excursion (FTE) of declarative sentences in S-V patterned to the informants accross generational or age groups. 
The acoustic features calculation was also carried out to determine the values of significance on BT, FT, TR, and FTE of the declarative sentences in subject-predicate-object (S-PO) patterned. The results described in below table 2 .

TABLE II. THE SignificANCES OF BASIC TONE (BT), FinAL TONE (FT), TONE RANGE (TR) AND FinAL TONE EXCURSION (FTE) OF The DeClarative SENTENCES OF SubJeCt-Verb-ObJeCt (SV-O) PATTERNED DHEWEKE NGOMBE SUSU ‘He DRINKS MILK'

\begin{tabular}{|l|l|l|l|l|}
\hline & BT $(\mathrm{Hz})$ & FT $(\mathrm{Hz})$ & TR $(\mathrm{Hz})$ & FTE $(\mathrm{Hz})$ \\
\hline 17-24 years old & 167,1535 & 173,3480 & 85,8811 & 6,1946 \\
\hline 25-49 years old & 165,1651 & 157,6863 & 75,9986 & $-7,4788$ \\
\hline $\begin{array}{l}\text { 50 years old } \\
\text { and over }\end{array}$ & 158,0452 & 132,8996 & 99,7789 & $-25,1456$ \\
\hline Significance & 0,909 & 0,264 & 0,453 & 0,111 \\
\hline
\end{tabular}

Information on table 2 shows the significance value that inclined towards insignificant ( $\mathrm{p}$ value over 0.05 ). In other words, all groups of age (1,2, and 3 ) expressed sentences in SPO patterned with basic tone (BT) which remains indifferent $(\mathrm{p}=0.909)$, final tone $(\mathrm{FT})$ similar $(\mathrm{p}=0.264)$, tone range (TR) indifferent $(\mathrm{p}=0.453)$, in addition to reflect final tone excursion (FTE) that results indifferent $(\mathrm{p}=0.111)$. This is as elaborated in Fig. 2.

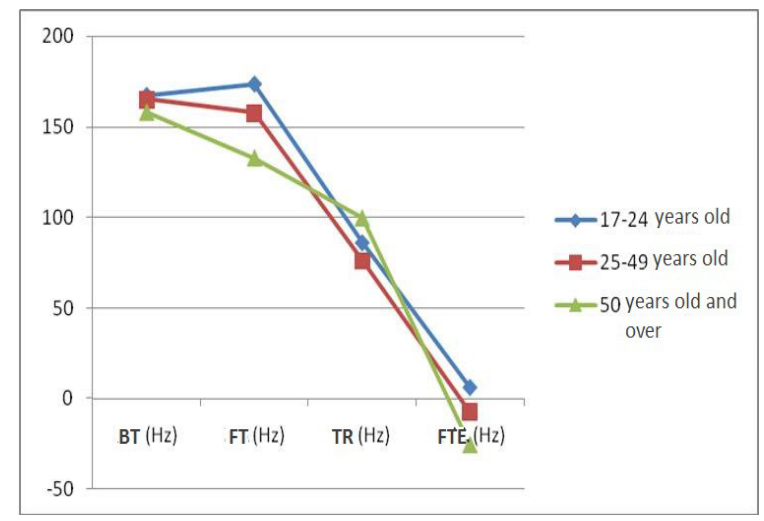

Fig. 2. The comparison between basic tone (BT), final tone (FT), tone range (TR), and final tone excursion (FTE) of declarative sentences in S-V-O patterned to informants of accross generations or age groups.

Regarding of the Subject-Verb-Object-Adverb patterned is illustrated in table 3 .

TABLE III. THE SIGNIFICANCES OF BT, FT, TR AND FTE OF DECLARATIVE SENTENCES IN SUBJECT-VERB-OBJECT (S-V-O-A) PATTERNed DHEWEKE NGOMBE SUSU NENG PAWON 'HE DRINKS MILK IN THE KITCHEN'

\begin{tabular}{|l|c|l|l|l|}
\hline & BT $(\mathrm{Hz})$ & FT $(\mathrm{Hz})$ & TR $(\mathrm{Hz})$ & FTE $(\mathrm{Hz})$ \\
\hline 17-24 years old & 177,6450 & 130,7164 & 92,3781 & $-46,9285$ \\
\hline 25-49 years old & 168,2057 & 139,6150 & 93,4394 & $-28,5904$ \\
\hline $\begin{array}{l}50 \text { years old } \\
\text { and over }\end{array}$ & 179,9438 & 130,2694 & 123,1167 & $-49,6748$ \\
\hline Significance & 0,857 & 0,844 & 0,116 & 0,323 \\
\hline
\end{tabular}

Intergenerational use of sentences in S-P-O-K patterned are indifferent. The results of significance calculations on BT,
FT, TR, and FTE in all declarative sentences type in S-P-O-K patterned leads to greater values than 0.05 . The significances of BT $(\mathrm{p}=0,857>0,50)$, FT $(\mathrm{p}=0,844>0,05)$, TR $(\mathrm{p}=$ $0,116>0,05)$, dan FTE $(\mathrm{p}=0,323>0,05)$. All these significance amount of values concludeable in which the Thus, the three generations or age groups (of 1,2, and 3) describe the typical expressed sentences in S-P-O-K patterned with basic tone, final tone, tone rang, and final tone excitemen. The Javanese language and culture environment lead the informants to be familiar with the everyday language use, consequentlu, when they express any sentence under similar pattern, autonomously will also express a typical style or melodious tone that more or less similar. The comparison of such a situation is illustrated in Fig. 3.

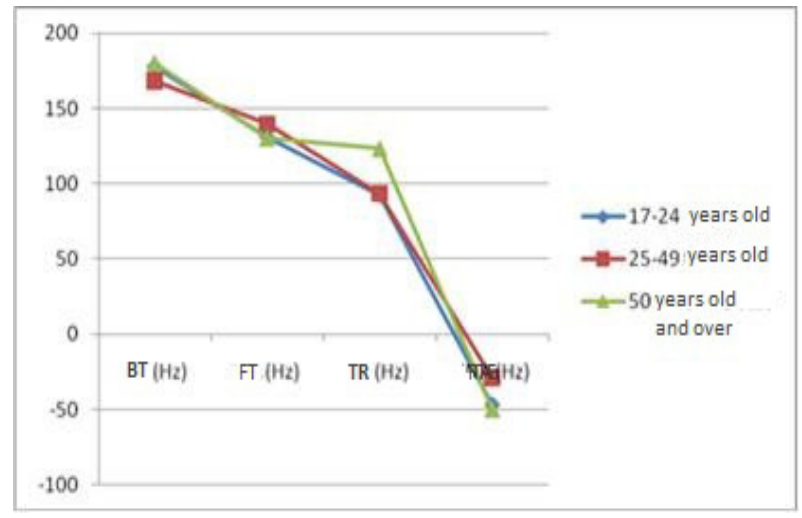

Fig. 3. The comparison between basic tone (BT), final tone (FT), tone range (TR), and final tone excursion (FTE) of the declarative sentences in $S-V-O-A$ patterned to infomants of accross generations or age groups.

Age directly divides the community into several age groups, among others are children, adolescents, and adults. The age limits of community cannot be determined with certainty. Age is a biological fact whose characteristics relate to various social organizations and various rules, such as school age rules, driving licenses, voting rights in elections, etc.

On the basis of such a case, in this study, age is divided into three: the first age 17 years up to 24 years old which according to some books of psychology are classified into adolescence, the second age of 25 years to 49 years old are classified into adulthood, and the third age is people over 50 years old are classified into elderly. Of the three age groups, the differences in terms of the language variations are quite obvious.

Adolescence in terms of human's development, is an interesting and impressive phase. Adolescence has specific behavioral characteristics associated with an attitude of adventure grouping (click) "misbehavior", including in language use case. The variety of adolescent speech is more unique and varied. The uniqueness is caused by the tendency of teenagers who like to form exclusive groups that differentiate them with the other, this consequently can 
produce languages a tyical inclusive and secret language (slang) which can only be understood by members of the group (Sumarsono, 2002, p. 150).

Adults in society are characterized by linguistic wellformedness or conformity under certain linguistic rules prevailing in each of their language use. The adults inclined towards showing their identity using the first language and remain preserving the first language even though they would also use second language and other language variations at different times.

Parents in general will speak more relaxed to younger speaking partners, while the younger ones speak more formal to elders. A research from New York found that as people reach their adults' age, he/she would use their native language dialects. Instead the younger speakers use the standard language (Holmes, 2013, p. 148).

The classifications of three age groups above, in general this study at least has found an inclination on specific use of Javanese language by inhabitants living in Yogyakarta, Central Java of Indonesia. The findings concern about speech duration or time that generally, the age group of 50 years old and over, have a longer duration of speech expression use to be compared with the age group of 25 years to 49 years old. Likewise, the age group of 25 years to 49 years old has a longer duration of speech expression to be compared with the age of 17 years to 24 years. This is in accordance with the above facts which distinguish age groups into adolescents, adults, and elderly.

The use of different languages between generations has also been suggested by a linguist who claimed that in linguistic system there are three successive generations $\left(G_{n}\right.$ $\mathrm{G}_{\mathrm{n}+2}$ ). In the transmissional process of the sequence of this generation, it is pointed out that there is a difference of speech from $G_{n}$ and $G_{n+1}$. In this case, there is a difference in the use of language in previous generations $\left(\mathrm{G}_{\mathrm{n}}\right)$ with the succeeding generations $\left(G_{n+1}\right.$ and $\left.G_{n+2}\right)$. This is not something absolute; the succeeding generations can either use language choice from the previous generation or can also choose only from a particular generation (Coulmas, 2005, p. 52-53).

In line with the findings on the basic tone, it was found in general that the ages of 17-24 years old inclined towards expressing a higher tone to be compared with those of age group between 25-49 years old. Similarly, the age group of 25-49 years has a higher basic tone instead of those the 50 years old and over. Such things happen according to the character of each age group ranging from adolescents, adults, to elderly.

Teenagers most often found venturing in the language use. These teens in everyday life often use language in accordance with typical language use as practiced in their groups. It is therefore natural that teenagers have a high basic tone instead of the other two groups because of the influence of their group language. On the other hand, the other two groups are always faithful to the first language rules that are supplemented by the non-formal elements in expressing a language. This will produce a basic tone which is not as high as the basic tone of teenagers.

The findings on basic tone are somewhat different from those found in the final tone. In the final tone, the age group of 24 years old to the 50 years old and over tends to use a lower ending tone instead of the final tone among the group of informants in between 17-24 years old. This essentially happened due to several determining factors of age, experience, maturity, and calmness in language use. Both classified people of adults and elderly age in their language expression use shows a typical more relax personality, and having a complete master of the language use. All of these qualifications is fundamentally influential to a better use of grammatical language, in addition to the intonation. Similarly, a grammatically correct speech of a language use will automatically produce a well-determined intonation.

The findings relate to tone range, wide or large pitch ranges are generally dominated by the older age groups (over 50 years old). A tone range is a range in between the highest tone difference with the lowest tone. The greater tone range of a speech will produce a melodious speech. This means that the rise and fall of the tone was used to produce appropriate and well-sounded tonal sentences, avoid monotonous or flat typical use of sentences. This happens especially because the researched subjects have not yet a lot of experience, balance and maturity as a language user in their community. The more aging a person, the more he/she masters vocabulary, and consequently the more they implement the prescribed rules in using a language.

On the analysis regarding the final tone excursion, ie the amount of tone drift with the basic tone, it was found that the age group of 25 years old and over use a wide final tone excursion to compare with the final tone excursion expressed by a group of people between 17-24 years old. This is in line with previous findings about tone ranges. The better the tonal sentence use, the greater the tone range, and the wider the final tone excursion.

\section{CONCLUSION}

From the results of declarative sentences pitch movement analysis or affirmative sentences, are the sentences that commonly expressed by speakers or authors to establish statements, therefore, the contents reflect only piece of information directed to listeners or readers, it is a commonsense that both the sentence of either in SP, SPO, or SPOK patterned, all of which experienced a reducing tone at the end of the sentence. This means that almost all of such typical sentences incline towards using higher final tone. In other words, on this typical sentence use, the tonal aspect of the sentence is expressed in decreased (Yustanto, 2018m p. 406).

This study is quite important, especially for the preservation of regional languages that gradually lead to extinction. Having found the pitch movement of Javanese 
language, it provides learners with significant information on how to produce a correct speech tone pattern. Pragmatically, these findings are very useful since the suprasegmental and context-specific speech likely to produce varied meanings. Likewise in the field of dialectology, different prosodies of the same word use may produce different dialect maps.

\section{References}

't Hart, J., Collier, R. \& Cohen, A. (2006). A perceptual study of intonation: An Experimental-Phonetics Approach to speech melody. Cambridge: Cambridge University Press.

Ball, M.J. \& N. Muller (2005). Phonetics for communication Disorder.USA: $\quad$ Lawrence Erlbaum Associates

Coulmas, Florian. (2005). Sociolinguistics: The study of speaker's choices. Cambridge: Cambridge University Press.

Holmes, Janet. (2013). An introduction to Sociolinguistics. London and NewYork: Routledge.

Ningsih, Tri Wahyu Retno. (2017). Karakteristik prosodi pada penutur autism spectrum disorder tipe verbal: Sebuah pendekatan Fonetik Eksperimental (Doctoral dissertation).

Roosman, L.M. (2006). Phonetics experiments on the word and sentence prosody of Betawi Malay and Toba Batak. LOT. (Doctoral dissertation).Dissertation Series 129. Utrecht: LOT.

Sudjana. (1989). Metoda Statistika (edisi ke-5). Bandung: Tarsito.

Sugiyono. (2003). Pemarkah prosodi kontras deklaratif dan introgatif bahasa Melayu Kutai (Doctoral dissertation). Depok: Pascasarjana Universitas Indonesia.

Sumarsono \& Paina Partono. (2002). Sosiolinguistik. Yogyakarta: Pustaka Pelajar.

Syarfina, T. (2008). Ciri akustik sebagai pemarkah sosial penutur bahasa Melayu Deli. (Doctoral dissertation). Medan: Pascasarjana USU.

Yustanto, H. (2018). Struktur prosodik bahasa jawa kodya yogyakarta dalam dimensi sosial dan emosional. (Doctoral dissertation). Surakarta: Universitas Sebelas Maret. 